\title{
Empowerment of The Deprived Young Population for Sustainable Futures in The Post Pandemic Era: An Evidence from Malaysia
}

\author{
Shereen Khan', Nasreen Khan ${ }^{1}$, Olivia Tan ${ }^{1}$ \\ ${ }^{1}$ Faculty of Management, Multimedia University, Malaysia
}

\begin{abstract}
The 2030 Plan for Sustainable Development Goals (SDGs) was approved by the United Nations General Assembly in 2015 on the principle of "leaving no one behind" in order to achieve sustainable development for everyone. The global pandemic has forced a lot of people to become jobless and in fact the unemployment rate has been increasing since the outbreak of Covid-19 pandemic across the globe. Youths have not been spared from this especially youth from the deprived population. This article looks into how the deprived young population can be empowered especially during the post pandemic era. The objectives of this article are to investigate and examine the post covid-19 recovery plan for young population in Malaysia and other jurisdictions to ensure that they are not left behind in nation building for sustainable futures. The main objective is thus to recommend the best practices and policy to be implemented to empower the deprived young population in the post pandemic era. A comparative study was conducted by analysing the policies in Malaysia and other selected jurisdictions. This article is basically emphasized on the current situation in Malaysia and the research was limited to secondary data becaused of the movement control order implemented in Malaysia to curb the spread of global pandemic. The findings of this article is to contribute to the policy makers in their effort to empower the youths from deprived society. Young people including those from the deprived population are the hope of stable future of the country.
\end{abstract}

Keywords: policy; post pandemic; youths; deprived population; sustainable future

This is an open access article under the CC-BY-NC license.

\section{INTRODUCTION}

The global outbreak of Covid-19 has had significant impact on all facets of life. The pandemic crisis poses significant risks in the fields of education, jobs, mental health and disposable income for young people especially vulnerable young people from the disadvantaged population. The job opportunities and education of young people have been badly hit by the global pandemic crisis, according to the International Labour Organization (ILO). Unless urgent action is taken, the effect of the pandemic is likely to be serious and permanent, particularly for young people in lowerincome countries. The impact is taking a toll on the deprived young population in Malaysia and across the ASEAN region and this population should be prioritised in recovery efforts. Although the risk of serious illness for older adults is higher, young people are likely to bear the brunt of longterm health, economic and social costs. Globally, young people aged between 10 and 24 make up 66 
million people, or 25 per cent of the total world population according to the data collected by World Bank in 2020. (World Bank 2020). Based on the data collected by the Department of Statistics Malaysia, youth contributes to 14.6 million aged between $15-39$ years old which is the $45 \%$ of the total population.

In Malaysia, it is therefore crucial to prioritize young people in the COVID-19 response and to commit to a recovery that includes and engages them as partners in finding solutions to the socioeconomic challenges the country faces. According to the United Nations Secretary-General António Guterres, the virus has affected young people across the globe badly, from lost work to family anxiety, mental wellbeing and other hardships. 1.54 billion young people around the world are out of school and young refugees, displaced people and those impacted by war or disaster are facing increased insecurity as a result of Covid-19 according to the survey conducted by UNICEF in December 2020.

Across all regions, as estimated by the International Labour Organisarion (ILO), the economic downturn is expected to affect with the potential to destroy more than 195 million jobs. In turn, this is expected to have a greater negative effect on some groups than others, especially people in less secure and low-paid jobs in particular youth from deprived population. The decline in youth employment will continue across the region in the Asia-Pacific and global attention should be turned to what the 'new normal' would look like as we progress into a post-pandemic world.

\section{LITERATURE REVIEW}

The research objectives are thus, to investigate the existing post covid-19 recovery plan for young population in Malaysia; to examine the post covid-19 recovery plan for young population in other jurisdictions and to recommend the best practices and policy to be implemented to empower the underprivileged youth population in the post pandemic era.

While the poorest communities in Malaysia are presumed to be the most vulnerable, another type of insecurity is taking shape upon the young people who are at the forefront of the economic effects of this worsening situation during the Covid-19 crisis. Throughout the planet, economies are being destroyed across the globe and millions are being thrown out of jobs. Malaysia - even before Covid-19, with a slowing economy - encountering challenges that will continue long after the end of movement control order (MCO). The truth is that in this global slowdown, millions of Malaysians will lose their jobs. Factories are now folding up and if they are closed down, many companies will not start up again. Nearly 6 million young people (15-29 years old) in the labour force encounter the highest risk of losing jobs and precocity; the slowdown of the job market and their comparatively lower wages would seriously limit their job opportunities. It is therefore important that the situation faced by younger Malaysians should be taken seriously, or else this generation will be left with an indelible imprint in the post-covid period.

Due to the spike of the Covid-19 cases in Malaysia, all schools across in Malaysia have been closed until the end of the school year in December. Most of the students and teachers especially from rural areas were not prepared for home-based learning when the movement control order was declared in March and till now, it has yet to be improved. Although, Ministry of Education has set up an online digital learning platform (Delima), most of the students cannot access to it. Internet connectivity especially for the students from deprived population were found to be insufficient and thus there is no equal and integrated home-based learning across the country during this pandemic 
crisis. Even for those who have access to internet connection and necessary devices among the households in urban areas, half of the population do not have a conducive place to study. Based on the survey conducted, these factors would resulted in these youth from deprived population to be completely disinterested in schooling and learning. Based on the survey conducted among the young students, it was found that lack of devices and internet access remained a problem for quality online learning especially students from deprived population. Losses in parental jobs lead to insufficient resources that place additional burden on families and can lead to problems with mental health. The additional pressures can also lead young people to be more prone to aggression or violence (Duckett, 2020). More young people especially from the poor community, drop out of school. The number of students returning to the classroom is falling at an unprecedented pace in Klang Valley alone. There are serious implications of dropping out of school, and even more so by rising the rate of crime. Based on statistics published on 13 October 2020 by the Department of Statistics Malaysia, the unemployment rate in August 2020 is 4.7 percent and the youth unemployment rate in Malaysia is estimated at 11.72 percent. Working hours for employed young people dropped by almost a quarter and their income was decreased by 42 percent. For the first quarter of 2020, job losses in the country were estimated to have risen by 42 percent year-on-year. To sum up, this pandemic has had a very serious effect on the youth of the deprived population, especially in the areas of education, mental health and employment. It is therefore critical that significant attention in Malaysia should be given to these problems affecting young people.

Several economic stimulus initiatives designed to ensure that all the welfare of people is taken care of have been made available by the Government of Malaysia. On 27 March 2020, the government announced the Prihtin Rakyat (Caring for People) package to ensure that no one is left behind An additional stimulus package was announced on 6 April 2020 to help small and mediumsized enterprises (SMEs) and micro enterprises that account for two-thirds of the workforce and 40 percent of the economy. To what extent these packaged have alleviated or assist the youth from deprived population is yet to be seen. However, survey conducted by the researchers on small minority from B40 groups has indicated that the money given are likely to be gone very soon though these stimulus packages did help in improving the negative cash-flow rates during the crisis. All these can be regarded as a short term remedial actions and there is still lacking of policy implementation on the long term recover efforts emphasising on the youth from deprived population. RM2 billion (US $\$ 479$ million) had been allocated under the Economic Recovery Plan to ensure the success of the Skills and Upskilling Programme. Malaysian media reported last June that youths who are jobless or retrenched will be retrained under the programme for free. The programme will benefit up to 200,000 youths, who will receive training allowance, as well as meals.

The growth of the younger generation is a priority of the Malaysian Government in all fields, including in the field of human resources. The government believes that young people are the generation that will ensure stability in the development of the country and should therefore be active in the process of policy development. Youth from the impoverished community are $42 \%$ of the participants in fellow programmes coordinated by the Government. Social security responses have been included among the interventions adopted by the Malaysian Government, covering a range of initiatives affecting various segments. Think of low-income cash grants, elderly pensions or specific youth skills training addressing social assistance, social security and labour market 
policies. Social assistance is intended to move resources, including Bantuan Prihatin Nasional, Bantuan Orang Tua and Bantuan Awal Persekolahan, to the correct segments through tax-financed benefits (cash or in kind) that can be universal, categorical or means checked, to name a few. Social insurance is an aggressive precautionary mechanism against risks that one takes. It may be partially funded by the government, such as government insurance, the Workers Provident Fund (EPF) or the Social Security Association (Socso), with contributions on a regular basis from employees and employers. Finally, through successful labour market strategies, labour exchanges and market demands, including pay and recruiting subsidy programmes, complete or productive employment is encouraged. Evidence suggests that countries with sound social security coped with shocks much better prior to the pandemic.

The year 2020 marks the conclusion of Vision 2020 and the Eleventh Malaysia Plan for the period 2016-2020 in Malaysia. A post-2020 development strategy with a specific strategic vision will continue to be developed in order to set the path forward for the next decade's national development agenda alongside the implementation framework. The 12th Malaysia Plan (12MP), scheduled to be tabled on 6 August, was postponed until January next year to enable the government to conduct a review following the effect of the Covid-19 pandemic on the global economy. In July 2019, Malaysia's government launched the National Entrepreneurship Policy 2030 to promote the growth of the country's deprived population (B40 Group) prior to this global pandemic outbreak. There is no simple and precise rehabilitation plan directed at the youth of the impoverished community. Malaysia therefore requires more detailed policies directed at the youth of the impoverished community. Although a variety of steps have been taken by most countries across the world to curb the spread of the virus, the disrupted nature of the Covid-10 pandemic allows governments the opportunity to respond decisively and efficiently, as these governments have to balance public health and economic considerations at the same time by allocating a wide range of economic stimulus packages across various sectors.

Whereas, in the ASEAN region, in collaboration with e-commerce platforms, the Government of Indonesia, state-owned Bank Negara Indonesia (BNI), e-wallet OVO and LinkAja, and edutech have introduced a pre-employment card programme to help employees impacted by the adverse economic impacts of the pandemic. The card is an alternative to learning new skills, upskills and reskills for those impacted by the COVID-19 (outbreak) and to help youth in their expertise and growth in their competitiveness. Organizations participating in the pre-employment card program e will choose eligible institutions that offer the requisite industry training and are open to Indonesians at least 18 years of age. It has also been estimated that at least IDR10 trillion (US\$680 million) has been allocated by the government to the programme, which is said to provide training for around two million citizens. In Philippines, Philippine Business for Education (PBEd), a non-profit organisation has urged local industries to help raise the skill levels of Philippine youths amid the pandemic to ensure they are workplace ready. The UN also released a statement encouraging stakeholders to promote skilling programmes for young people. The organisation stated that it has a domino-effect which help in making significant strides towards the Sustainable Development Goals (SDGs). In fact, not only does it contribute in attaining SDG 8 (decent work and economic growth) by providing more opportunities to work, it also helps in achieving SDG 1 (no poverty), SDG 2 (zero hunger), SDG 3 (good health and well-being), SDG 4 (quality education), and SDG 16 (partnership for the goals). Several OECD countries, have initiated e-participation projects, 
including Estonia, Germany, Poland and Switzerland, to involve people in post Covid-19 efforts to recover. Italy has set up a task force for multi-stakeholder to tackle the spreading of pandemicrelated misinformation. Initiatives on youth development and international justice have several of these policies. In Spain, a forum is used for crowdfunding in collaboration with other investors, a collaborative and participatory investment vehicle to help start-ups that are working on solutions to issues caused by the COVID-19 crisis.

\section{RESEARCH METHOD}

This paper focused on the policies and social programmes in Malaysia and the recovery plan of post Covid-19 in Malaysia and other jurisdictions across the globe. This is a conceptual paper and further research should be conducted by using both quantitative and qualitative research method to produce an evidence based research paper. Input from the young people themselves will make it easier and more efficient in solving the issues faced by the policy makers. A comparative study was conducted by analysing the policies in Malaysia and other selected jurisdictions. It also involved a review of the International Instruments and other academic literature on the impact of Covid-19, youth post pandemic recovery and youth resilience. Because of the movement control order implemented across the country in Malaysia, data used were secondary data based on the literature review.

\section{FINDINGS AND DISCUSSION}

The world is radically transformed because of the global pandemic. The empowerment of individuals especially the youth will have dramatic impact. COVID-19 is a generational pandemic that will have a disproportionate long-term effect on young people. Present policies and social services with an emphasis on the disadvantaged youth population in Malaysia should be reviewed and revised to ensure that they are not left behind in nation building for sustainable futures.

The pandemic's serious economic and labour market effect on youth employability and jobs calls for immediate, large-scale and tailored responses. A holistic and targeted strategy must be at the centre of the Youth Jobs and Recovery Package, which includes the provision of youth-targeted wage subsidy services, support for youth in career readiness and job search assistance, enhancement of youth access to reskilling and upskilling, and youth investment. With regards to the issue relating to education of the youths, the longer they are out of education, the more likely they are to drop out altogether. Many also feel anxious about returning to school, adding to stresses and possible increase in drop out, so it is crucial to scale-up options for home learning including notech and low-tech options. When schools reopen, investments in quality education and skills development must be increased to ensure a generation of children and young people is not left behind. As millions of parents struggle to sustain their livelihoods and earnings through the economic downturn, governments must sustain financial support to families through social protection programmes, including cash transfers, to ensure equal opportunity for every child. Access to key social services and mental health support must be a priority - preparing for an increase in demand, supporting children remotely and investing in a social workforce. When planning their COVID-19 response, the specific risks faced by the youth particularly prejudice and stigma should be accounted for by the government. 
Unemployment among young people is one of the first to rise, and one of the last to recover. More than 30 percent of youth in Malaysia are jobless and causing this generation of young workers to experience long-term economic scarcity. Urgent and adequate measures that put employment needs of the youth need to be incorporated in post-Covid 19 economic recovery plan focusing more on job creation and empowering of young people who run small and medium enterprises. In order to support the complex challenges facing young people, more mental health resources are needed to offer free, secure and better prepared services. And this is particularly relevant now that we are forming a post-covid era.

\section{CONCLUSION \& FURTHER RESEARCH}

Government should actively seek to partner with and support youth initiatives across the economy. The Sustainable Development 2030 Plan recognises young people as crucial agents of change. Each of the 17 Sustainable Development Goals (SDGs) is based on action by young people. This tough moment is a time for young people to do what they do best: self-organize self-mobilize and pool their energy for global solidarity actions.

Specific policy interventions have been required to solve the issues faced by the youth in general and in particular youth from the deprived population in Malaysia. Young people including those from the deprived population are the hope of stable future of the country. The virus has highlighted the problems that are expected to cater to and protect those in need in the social and economic structures. To support social economy organisations to bounce backs in the short term and sustainable future for the long term, a combination of policy measures is required. Policies that encourage social innovation and collaboration will enable developments in the social economy to increase their impact.

Many youths desire to use what they learnt in school in employment. Unfortunately, the business, economic and political environment that can actualise that is unavailable. Depression then creeps in. Before we know it, suicides and drug abuse levels hit an all-time high. To correct this, urgent and adequate measures that put employment needs of the youth need to be incorporated in post-Covid 19 economic recovery plan.

\section{REFERENCES}

Duckett, S. (2020), 'Coming Out of Covid-19 Lockdown,' [Online], [Retrieved October 3, 2020], https://grattan.edu.au/wp-content/uploads/2020/06/Coming-out-of-COVID-lockdownthe-next-steps-for-Australian-health-care.pdf

EASPD (European Association of Service Providers with Persons with Disabilities) (2020), COVID-19: how social enterprises are fighting back!, https://www.easpd.eu/en/content/covid-19how-social-enterprises-are-fighting-back.

OECD (2020), Coronavirus (COVID-19) From pandemic to recovery: Local employment and economic development, [Online], [Retrieved October 5, 2020]. http://www.oecd.org/coronavirus/policy-responses/from-pandemic-to-recovery-localemployment-and-economic-development-879d2913/.

OECD (2020), Coronavirus (COVID-19): SME policy responses, [Online], [Retrieved October 3, 2020], http://www.oecd.org/coronavirus/policy-responses/coronavirus-covid-19-sme-policyresponses-04440101/. 
OECD (2020), Policy implications of Coronavirus crisis for rural development, [Online] [Retrieved October 3, 2020] http://www.oecd.org/coronavirus/policy-responses/policyimplications-of-coronavirus-crisis-for-rural-development-6b9d189a/\#figure-d1e543.

OECD (2020), Policy Responses to Coronavirus (COVID-19): Youth and COVID-19: Response, recovery and resilience, [Online], [Retrieved October 3, 2020], http://www.oecd.org/coronavirus/policy-responses/youth-and-covid-19-response-recoveryand-resilience-c40e61c6/

Pirlea, A. F., U. Serajuddin, D. Wadhwa, M. Welch and A. Whitby, eds. 2020. Atlas of the Sustainable Development Goals 2020: From World Development Indicators. Washington, DC: World Bank. https://datatopics.worldbank.org/sdgatlas/

The ASEAN POST, (2020), Pandemic Could Inflict Severe Damage on Youth, [Online], [Retrieved October 5, 2020], https://theaseanpost.com/article/pandemic-could-inflict-severedamage-youth

The EDGE Markets, (2020), The State of the Nation: Incentives to hire, upskill and retrain youth needed in Budget 2021, [Online], [Retrived October 20], https://www.theedgemarkets.com/article/state-nation-incentives-hire-upskill-and-retrainyouth-needed-budget-2021

UNICEF Australia. (2020). "Living in Limbo": The views and experiences of young people in Australia at the start of the COVID-19 pandemic and national response. [Online], [Retrieved October 5, 2020], https://www.unicef.org.au/Upload/UNICEF/Media/Documents/UNICEF-COVID-19Living-in-Limbo-2020.pdf.

Unicef. (2020), “COVID-19: Young people should be prioritized in recovery efforts,' [Online], [Retrieved October 3, 2020], https://www.unicef.org/indonesia/press-releases/covid-19-youngpeople-should-be-prioritized-recovery-efforts

Wood, D. (2020). The way out of the COVID-19 recession. Grattan Institute. [Online] [Retrieved October 5, 2020], https://grattan.edu.au/news/the-way-out-of-the-covid-19recession/. 